\title{
SCIENTIFIC CIVIL SERVICE
}

\author{
PROMOTION OF INDIVIDUAL RESEARCH WORKERS
}

$I^{\mathrm{T}}$ is announced that, as in previous years, special posts have again been created to provide for the promotion in the Scientific Civil Service of individual research workers of exceptional merit. These promotions, which include for the first time one to the grade of chief scientific officer, are effective from July 1.

\section{Chief Scientific Officer}

Mr. S. B. Gates has been at the Royal Aircraft Establishment, Ministry of Supply, since 1915, where he has acquired a reputation as one of the leading authorities in Great Britain on fundamental problems in aerodynamics. He has been particularly concerned with control problems, and the comparative ease with which the modern high-speed aircraft can be handled by the pilot owes much to his work.

\section{Deputy Chief Scientific Officers}

Sir Donald Barley joined the Experimental Bridging Establishment, now the Military Engineering Experimental Establishment, Ministry of Supply, in 1929 and has been continuously working on design and devèlopment of bridging equipment for the Army. His most spectacular achievement is the bridge which bears his name, which has been found to have outstanding advantages in other fields of civil engineering.

DR. F. E. Jones joined the Telecommunications Research Establishment, Ministry of Supply, in 1940 and played a large part in the development of electronic circuits used in radar equipment for the R.A.F. $\mathrm{He}$ has also played a prominent part in the application of radar techniques to the study of weather and of weather forecasting.

DR.K. M. SмIтH, director of the Plant Virus Research Unit, Cambridge, of the Agricultural Research Council, is a noted authority in the field of plant virus research. $\mathrm{He}$ has described many new virus diseases of horticultural and other plants and has investigated their transmission by insects and other means; he has studied the causal viruses by filtration and electron microscopy and, more recently, has greatly extended knowledge of the polyhedral diseases of insects. He is the author of a number of books on plant virus diseases.

Dr. R. L. M. SYNGE, of the Rowett Research Institute, was jointly responsible with Dr. A. J. P. Martin for the early study and development of partition chromatography as an analytical procedure. $\mathrm{He}$ is also known for his structural studies on the nature of gramicidin, and, more recently, for his chemical studies of the nitrogenous compounds in green leaves and micro-organisms and the influence of degradation of protein in the rumen on its utilization by the ruminant animal. $\mathrm{He}$ is continuing to develop physicochemical techniques, such as electrophoretic ultra-filtration, for the analysis of substances of biochemical interest.

\section{Senior Principal Scientific Officers}

Mr. G. BRAdFIELd joined the National Physical Laboratory in 1949 to initiate work on ultrasonics after experience since 1923 in industry, the Air Ministry and the Telecommunications Research
Establishment, Malvern. His earlier work was concerned mainly with the design and development of radio valves and centimetre radar, including responsibility for the design of complex war-time navigational devices. Since 1945 he has been engaged primarily in ultrasonic studies and is now a recognized authority on the subject. $\mathrm{H}_{\theta}$ is perhaps best known for the techniques developed for various purposes, such as flaw detection and the determination of elastic constants of crystals of isotropic and anisotropic solids over wide temperature ranges. In these fields the use of barium titanate as a novel piezoelectric material of high coupling has been explored and has yielded much improved devices.

Dr. W. P. K. Findlay, who is officer in charge of the Mycology Section of the Forest Products Research Laboratory, is a graduate of the Imperial College of Science and Technology, London, where he was awarded the Edward Forbes Medal and a Remanet Fellowship. In 1925, on a Fellowship of the Empire Cotton Growing Corporation, he studied first at Cambridge and later in Trinidad. In 1927 he joined the Forest Products Research Laboratory and was associated with K. St. G. Cartwright at the beginning of the Laboratory's systematic investigation into fungal decay in timber. As a result the technique of recognition, in the absence of fructification, of the fungi responsible for various kinds of wood rot by growing them in cultures was developed and has led to the establishment of the Wood Destroying Fungi Section in the National Collection of Fungi. $\mathrm{He}$ has also undertaken the mycological aspects of comprehensive investigations into the influence of fungal infection on the mechanical properties of wood. Dr. Findlay has been joint honorary secretary of the Biological Council from its inception in 1945 and has also been president of the British Mycological Society.

Mr. A. H. Fond-Moore has served in the Chemical Defence Experimental Establishment of the Ministry of Supply since 1921. He has played a leading part in chemical research into methods of defence against chemical warfare. $\mathrm{He}$ is an outstanding experimentalist and well known for his work on the organic chemistry of sulphur and phosphorus.

Dr. M. H. HEY, of the Department of Mineralogy, British Museum (Natural History), is a mineralogist and chemist of outstanding quality. His work on zeolites and his correlation of their properties with their crystal structure, and especially his study of the role of water in their constitution, was done between 1930 and 1937. He has specialized in inorganic microanalysis, and it is due to him that the chemical composition, and therefore the crystal structure and content of the unit cells of many new minerals, have been established. In addition to his chemicomineralogical work, Dr. Hey has charge of the great collection of meteorites in the Natural History Museum; in this work he has contributed many analyses of new meteorites and has just completed a new catalogue of the collection. He is the author of "An Index of Mineral Species and Varieties arranged Chemically".

Mr. W. R. Lane joined the Chemical Defence Experimental Establishment of the Ministry of Supply 
in 1929. His work has been mainly concerned with the physics of chemical defence problems, in which field his fundamental studies on the mechanism of the break-up of liquid drops and the formation of aerosols has contributed materially to present-day knowledge. His ingenious microburette for accurately delivering small drops of known size has now become a well-known instrument which is used in laboratories all over the world.

DR. J. G. NAGELSCHMIDT, of the Safety in Mines Research Establishment, is a mineralogist of international reputation and is now engaged on research into the mineralogical aspects of pneumoconiosis. He has been a pioneer in the application of X-ray diffraction techniques to the study of clay materials, in the application of new mineralogical techniques to the study of dusts responsible for lung disease, and in the application of the electron microscope to the study of clay minerals and dusts. He has developed and is still developing new techniques for the quantitative mineralogical analysis of small dust samples and for the identification of particular mineral particles too small for identification with the optical microscope. He is a member of the Industrial Pulmonary Diseases' Committee of the Medical Research Council and is secretary of the SubCommittee on Dust.

DR. H. H. M. PIKE joined the staff of the Research Department, Woolwich, now under the Ministry of Supply, in 1932, his early work being concerned with the internal ballistics of guns. More recently he has turned his attention to the study of the phenomena occurring during the detonation of high explosives, and his findings are the basis of civil defence teaching in connexion with the effects of blast on buildings.

Mr. J. S. Preston has been at the National Physical Laboratory for the past twenty-five years and was at first concerned with the development of photometric and radiometric methods of measurement. 'Through his work a standard design for commercially produced photo-emissive cells for precision photometry has been adopted. Later his attention was attracted to selenium cells, and he undertook investigations into their use in physical photometry; but the wide divergence between the theory and their practical behaviour led to a detailed investigation into the fundamentals of the constitution of rectifying contacts. This in turn was followed by work on the deposition and properties of a wide variety of thin films, and in this connexion the most recent development is the discovery of the technique necessary for the deposition on glass of a transparent electrically conducting metallic film of low resistance; this will have considerable practical value, as an electric current passing through the film will generate sufficient heat to prevent the deposition of moisture. Mr. Preston was the general secretary of the International Commission on Illumination during. $1932-49$.

DR. J. Thomblnson joined the Royal Aircraft Establishment, Ministry of Supply, in 1939, where his work has been directed to the problems connected with the landing and take-off of aircraft from.ships at sea and from confined spaces on land. He carried out the first known fundamental investigation into the performance of arrester gears used in deck landings of aircraft, and he originated and has since been responsible for the development of the flexible deck system for landing high-speed aircraft.

Mr. C. K. ThornhILL entered the Ministry of Supply in 1940 and has been attached to the Arma- ment Research Fstablishment since 1943. Throughout this period he has worked with conspicuous success on mathematical problems connected with guns and explosions. His contributions to the field of gun erosion were recognized by the United States Government in 1947 by the award of the American Medal of Freedom.

Mr. J. H. Whitakkr, who joined the Royal Aircraft Establishment, Ministry of Supply, in 1936, is a mechanical engineer and has made valuable contributions in many fields. He became a recognized authority on aircraft fuel and oil systems during the Second World War and has since been responsible for the development of essential components for guided missiles.

\section{PHYSICAL SOCIETY}

ANNUAL GENERAL MEETING

A $\mathrm{T}$ the annual general meeting of the Physical I Society, held at the Royal Institution on May 20 , the reports of the Council and of the honorary treasurer and the accounts and balance sheet for 1951 were presented and adopted. The officers and Council for 1952-53 were elected (see Nature, June 14, p. 995). At the extraordinary general meeting held immediately prior to the annual general meeting, Profs. Otto Hahn and M. T. von Laue were elected to honorary fellowship of the Society, and certain changes in the articles of association of the Society, which would make the procedure of election of officers and Council more democratic, were agreed to be submitted to the Board of Trade for approval.

During 1951, the Council reports, the membership rose to 2,025 and the activities of the Society again increased. It is gratifying to note that the decline in recent years in the number of newly elected Fellows has been arrested and that there have been substantial increases in both the studentship and fellowship grades. The work of the Society has been considerably hampered by rising costs of publication and shortage of paper, and the Council has given earnest consideration to the possibility of effecting economies and increasing efficiency. A scheme for introducing a reduced basic subscription for membership of the Society, with separate payment for all publications, has received considerable support and it is likely that some such scheme will be adopted for operation in 1953. Closer collaboration has been effected between the Society and the Institute of Physies, and members now receive notice of meetings of the Institute, which they are invited to attend. They may also obtain one of the Institute's two journals at a reduced subscription-rate.

In addition to nine science meetings held in London during the year, a two-day meeting was held at University College, Southampton, and three-day meetings at University College, Swansea, and at the Queen's University, Belfast. In April a conversazione for members and their friends was held in the rooms of the Royal Society and the Royal Geographical Society. The seventeenth Thomas Young Oration was delivered by Prof. W. D. Wright, who spoke on modern problems in colorimetry; the thirty-fifth Guthrie Lecture by Prof. N. F. Mott, on the mechanical properties of solids; and the 1951 Parsons Memorial Lecture by Mr. F. Twyman, on Sir Charles Parsons and optical engineering. Sir Thomas Merton 